\title{
lodized Salt Consumption in Sudan: Present Status and Future Directions
}

\author{
Mohamed Salih Mahfouz', ${ }^{1,2}$ Abdelrahim Mutwakel Gaffar ${ }^{1,3}$, Ibrahim Ahmed Bani ${ }^{1,3}$ \\ 'Family and Community Medicine Department, Faculty of Medicine, Jazan University, Saudi Arabia; ${ }^{2}$ Population Studies Center, \\ Gezira University, Sudan; ${ }^{3}$ Member of the International Council for the Control of lodine Deficiency Disorders (ICCIDD)
}

\begin{abstract}
Iodine Deficiency Disorders (IDD) Control Programme in Sudan adopted salt iodization as the long-term strategy in 1994. In 2000, it was found that less than 1\% of households were using adequately-iodized salt. The objectives of this study were to: (i) study the coverage and variation of different geographical regions of Sudan regarding access to and use of iodized salt, (ii) explore the possible factors which influence the use of iodized salt, (iii) develop recommendations to help in the implementation of the Universal Salt Iodization (USI) strategy in Sudan. This paper is based on the Sudan Household Health Survey (SHHS) dataset. A total sample of 24,507 households was surveyed, and 18,786 cooking salt samples were tested for iodine levels with rapid salt-testing kits. Nationally, the percentage of households using adequately-iodized salt increased from less than $1 \%$ in 2000 to $14.4 \%$, with wide variations between states. Access to iodized salt ranged from $96.9 \%$ in Central Equatoria to $0.4 \%$ in Gezira state. Population coverage with iodized salt in Sudan remains very low. The awareness and political support for USI programme is very weak. National legislation banning the sale of non-iodized salt does not exist. Utilization of the already-existing laws, like the National Standardization and Metrology Law (2008), to develop a compulsory national salt specification, will accelerate the USI in Sudan.
\end{abstract}

Key words: Iodine deficiency disorders; Salt legislations; Universal Salt Iodization; Sudan

\section{INTRODUCTION}

Iodine is an essential element for growth and development of humans and animals because it is a constituent of the thyroid hormones which play a crucial role in metabolism. The term 'iodine deficiency disorders' (IDD) refers to all the effects of iodine deficiency on growth and development in human and animal population (1). IDD increases the risk of cretinism, stillbirth, miscarriage, and infant mortality. In developing countries, about 38 million newborns every year are unprotected from the lifelong consequences of brain damage associated with iodine deficiency disorders (2). Elimination of iodine deficiency partly contributes to achieving the Millennium Development Goals agreed upon

Correspondence and reprint requests:

Dr. Mohamed Salih Mahfouz

Family and Community Medicine Department

Faculty of Medicine

Jazan University

PO Box 114

Jazan

Saudi Arabia

Email: mm.mahfouz@gmail.com by UN Member States in 2000. Meeting these goals would transform the lives of millions of children and families (2).

Universal Salt Iodization (USI) strategy to ensure sufficient intake of iodine by all individuals was recommended by the WHO and UNICEF Joint Committee on Health Policy in 1994 (3). Salt iodization is a remarkably cost-effective public-health strategy. On average, the one-time increase in cost is only 3-5 cents per person per year-a price so low that even consumers in the least developed countries would barely notice it (4). There are two forms of iodine in iodized salt: 'iodide' and 'iodate', usually as the potassium salt. Both are generally referred to as 'iodized' salt $(3,5)$. Iodate is recommended as the preferred fortificant because it is much more stable. Nearly $70 \%$ of the salts for humans and livestock in the world are iodized today (4). UNICEF estimates that less than $20 \%$ of households in the developing world were using iodized salt in the early 1990s, and by 2000 , the average had jumped to $70 \%$ (2). By 2006, around 120 countries were implementing salt iodization programmes (2). 
Worldwide, 34 countries have eliminated iodine deficiency disorders through Universal Salt Iodization (USI). Throughout the Middle East and North Africa region, $64 \%$ of households consume adequatelyiodized salt, with wide variation between countries. The Islamic Republic of Iran, Lebanon, and Tunisia are considered to have achieved the goal of Universal Salt Iodization (6). In Algeria, Egypt, Jordan, the Occupied Palestinian Territory, Oman, and the Syrian Arab Republic, household consumption of adequately-iodized salt is at least 50\%. In Sudan, Iraq, and Yemen, the consumption of adequatelyiodized salt is extremely low $(2,6)$.

IDD Control Programme in Sudan started in October 1989, using Lipiodol in some of the highlyendemic regions of the country and adopted salt iodization as the long-term national strategy in 1994 (7). By 2000, only 0.6\% households were consuming adequately-iodized salt in Northern Sudan while in Southern Sudan, it was less than $0.5 \%$. The percentage of households using adequately-iodized salt ranged from $0.1 \%$ in River Nile state to 3.6\% in South Darfur state. One percent of urban households were using adequatelyiodized salt compared to $0.4 \%$ of rural households (8). A comprehensive study conducted in 2006 showed that the goitre prevalence (GP) in school children aged 6 to 12 years in Sudan was found to be $38.8 \%$ overall, ranging from $12.2 \%$ in Omdurman to $77.7 \%$ in Kosti city (9). The urgent need for and the progress toward Univesrasl Salt Iodization in different Sudanese states were felt and discussed in many regional studies $(10,11,12)$.

The objectives of this study are to: (i) study the coverage of and variation in different geographical parts of Sudan regarding access to and use of iodized salt, (ii) explore the possible factors which influence the use of iodized salt, and (iii) develop recommendations to help in the implementation of the USI strategy in Sudan.

\section{MATERIALS AND METHODS}

Sudan is the largest country in Africa with an area of about 2.5 million kilometres. It neighbours nine countries with wide-open borders. The population in Sudan was estimated at 39.2 million in 2008, and the majority (72\%) lives in rural areas (13).

This study was based on the dataset of the Sudan Household Health Survey (SHHS) conducted in 2006. The survey was implemented by the Federal
Ministry of Health (FMoH), the Central Bureau of Statistics (CBS), and the Ministry of Health (MoH), together with the Southern Sudan Commission for Census Statistics and Evaluation (SSCCSE) (14).

The SHHS provides valuable information on the health situation of households, children, and women in Sudan. The survey was initiated, in a large part, on the need to have a baseline national data to monitor progress toward goals and targets emanating from national plans and international agreements-the Millennium Development Goals (MDGs). The sample for SHHS was designed to provide estimates on some key indicators of the health situation of children and women at the national level and in the 25 states of Sudan. In each state, a sample of 1,000 households was drawn for the survey.

The household questionnaire covered a number of topics, such as education, water and sanitation, household income and resources, use of insecticidetreated nets, salt iodization, and maternal mortality.

Of the 24,527 households initially selected as the sample, 24,507 households were found to be occupied. Of these, 24,046 households were successfully interviewed for a household response rate of $98.1 \%$. During the SHHS, 18,786 cooking salt samples were tested for iodine levels (eg. presence of potassium iodate) with rapid salttesting kits (RTK), using colour reference indicator.

The Statistical Package for Social Science (SPSS, version 17) was used for analyzing the data. General tabulations including frequency distribution were used. Chi-square test was used for testing some associations between the dependent variable (iodized salt) and a set of independent variables. The iodized salt test variables were recoded into two codes only, either using iodized salt (positive test) or not using iodized salt. In each case, a test of independence was performed using chi-square test of independence. The independent variables that assumed to affect the use of iodized salt (dependent variable) are: education of the head of the household, gender, mode of living, the region, and wealth index.

\section{RESULTS}

Table 1 illustrates the regional distribution of households according to the use of iodized salt and adequacy of salt iodization. One in seven households (14.4\%) in Sudan was using ade- 


\begin{tabular}{|c|c|c|c|c|}
\hline \multirow[b]{2}{*}{ Category } & \multicolumn{3}{|c|}{ Salt test result* } & \multirow{2}{*}{$\begin{array}{c}\text { Total } \\
\text { No. }(\%)\end{array}$} \\
\hline & $\begin{array}{l}\text { Not iodized } \\
\text { No. }(\%)\end{array}$ & $\begin{array}{l}<15 \mathrm{ppm} \\
\text { No. }(\%)\end{array}$ & $\begin{array}{l}>15 \mathrm{ppm} \\
\text { No. }(\%)\end{array}$ & \\
\hline \multicolumn{5}{|l|}{ Region } \\
\hline Northern & $1,926(98.5)$ & $23(1.2)$ & $7(0.4)$ & $1,956(100)$ \\
\hline Eastern & 2,733 (95.0) & $66(2.3)$ & $77(2.7)$ & $2,876(100)$ \\
\hline Khartoum & 937 (98.2) & $8(0.8)$ & $9(0.9)$ & $954(100)$ \\
\hline Central & 3,813 (98.9) & $21(0.5)$ & $21(0.5)$ & 3,855 (100) \\
\hline Kordofan & $1,714(91.9)$ & $66(3.5)$ & $85(4.6)$ & $1,865(100)$ \\
\hline Darfur & $1,812(63.0)$ & $196(6.8)$ & $866(30.1)$ & $2,874(100)$ \\
\hline Upper Nile & $430(52.1)$ & 318 (38.5) & $77(9.3)$ & 825 (100) \\
\hline Bahar-Algazal & $509(34.0)$ & 473 (31.6) & 517 (34.5) & 1,499 (100) \\
\hline Equatoria & $240(11.5)$ & 799 (38.4) & $1,043(50.1)$ & 2,082 (100) \\
\hline \multicolumn{5}{|l|}{ Mode of Living } \\
\hline Urban & $4,344(72.6)$ & 439 (7.3) & $1,198(20.0)$ & $5,981(100)$ \\
\hline Rural & $9,770(76.3)$ & $1,531(12.0)$ & $1,504(11.7)$ & $12,805(100)$ \\
\hline Total & $14,114(75.1)$ & $1,970(10.5)$ & $2,702(14.4)$ & $18,786(100)$ \\
\hline
\end{tabular}

quately-iodized salt, i.e. $>15$ parts per million. Twenty percent of urban population and $11.7 \%$ of the rural population are using adequatelyiodized salt. The percentage of household using adequately-iodized salt ranged from 50\% in Equatoria region to less than $0.5 \%$ in Northern region. People's access to iodized salt ranged from $88 \%$ in regional sector to $1 \%$ in the central region (Table 1 ).

Table 2 as well as Figure 1 classify the Sudanese states into four groups, based on the percent-

Table 2. Classification of states according to the percentage of households having access to iodized salt

\begin{tabular}{|ll|}
\hline \multicolumn{1}{|c|}{ Group } & \multicolumn{1}{c|}{ State } \\
\hline $\begin{array}{l}\text { Group 1: } \\
\text { More than } 90 \% \text { of the households } \\
\text { having access to iodized salt }\end{array}$ & $\begin{array}{l}\text { Only one state: Central Equatoria (iodized-96.9\%; } \\
\text { adequately iodized-78.9\% ) }\end{array}$ \\
\hline
\end{tabular}

Group 2:

$50-90 \%$ of the households having access to iodized salt

Group 3:

$20-50 \%$ of the households having access to iodized salt

Group 4:

Less than $20 \%$ of the households having access to iodized salt
7 states: Upper Nile (iodized-87.4\%, adequately iodized$14.6 \%$ ); Lakes (iodized-84.6\%, adequately iodized-59.3\%); West Equatoria (iodized-81.4\%, adequately iodized13.4\%); East Equatoria (iodized-81.1\%, adequately iodized-50.5\%); Warab (iodized-77.3\%, adequately iodized-11.7\%); Unity (iodized-58.3\%, adequately iodized-10.8\%); West Bahr Al-Gazal (iodized-57.7\%, adequately iodized-31.4\%)

5 states: West Darfur (44.1\%), Northern Darfur (44.0\%), Northern Bahr Al-Gazal (39.7\%), Jongolei (26.1\%), South Darfur (23.0\%)

12 states: Northern Kordofan (8.2\%), Red Sea (8.0\%), South Kordofan (8.0\%), Gadarif (4.4\%), Kassala (2.6\%), River Nile (2.0\%), Khartoum (1.8\%), White Nile (1.5\%), Sinnar (1.5\%), Northern state (1.0\%), Blue Nile (1.0\%), Gezira (0.4\%) 


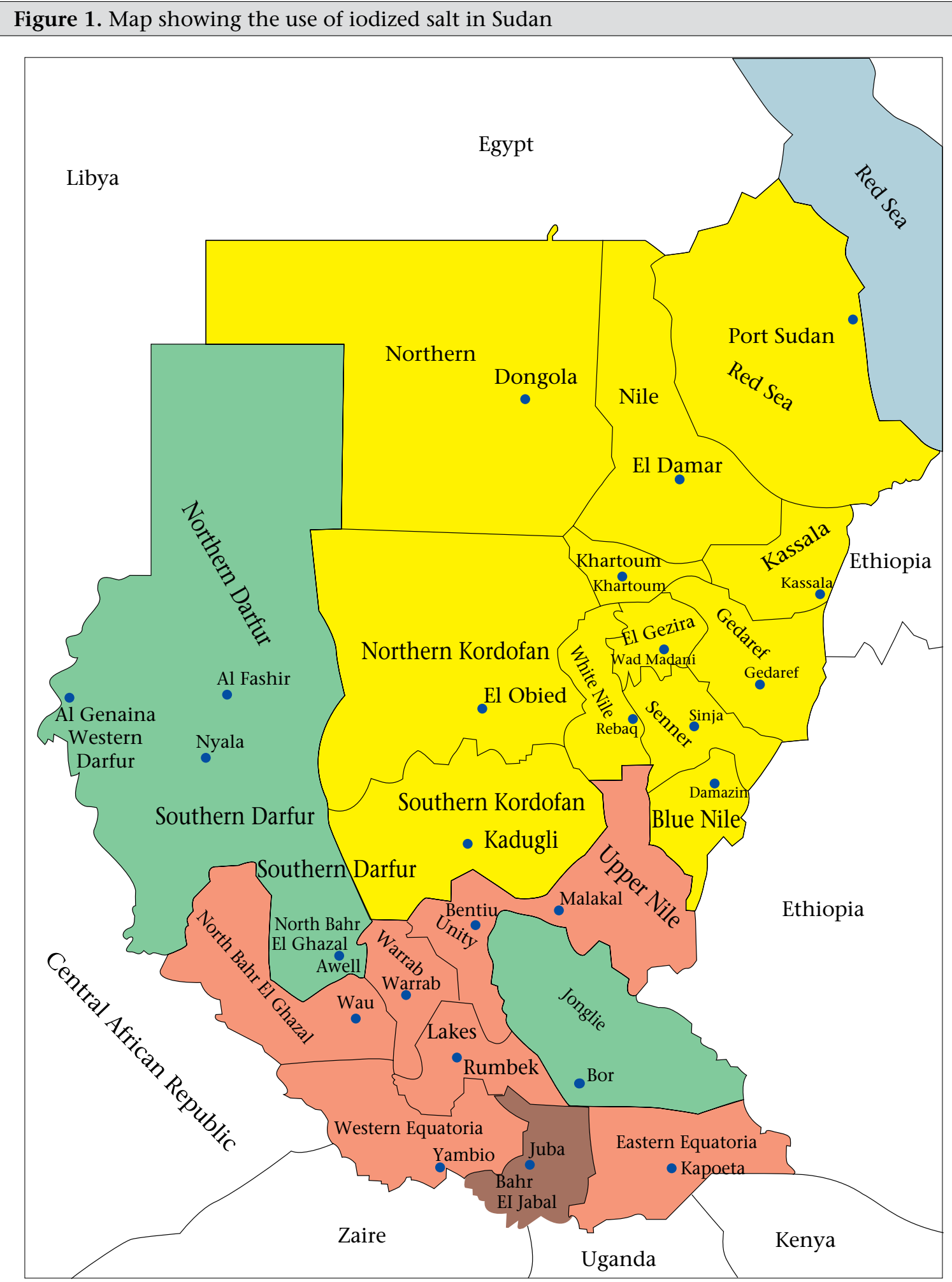

\section{Legend}

More than $90 \%$ of the households having access to iodized salt

$50-<90 \%$ of the households having access to iodized salt
$20-<50 \%$ of the households having access to iodized salt

Less than $20 \%$ of the households having access to iodized salt 


\begin{tabular}{|c|c|c|c|c|c|c|c|c|}
\hline \multirow{3}{*}{$\begin{array}{l}\text { Sectors } \backslash \text { test } \\
\text { results* }\end{array}$} & \multicolumn{8}{|c|}{ Source of salt } \\
\hline & \multicolumn{3}{|c|}{ Local market-No. (\%) } & \multirow[b]{2}{*}{ Total } & \multicolumn{3}{|c|}{ Food Aid-No. (\%) } & \multirow[b]{2}{*}{ Total } \\
\hline & $\begin{array}{c}\text { Not } \\
\text { iodized }\end{array}$ & $\begin{array}{c}<15 \\
\text { pmm }\end{array}$ & $\begin{array}{l}>15 \\
\text { pmm }\end{array}$ & & $\begin{array}{c}\text { Not } \\
\text { iodized }\end{array}$ & $\begin{array}{c}<15 \\
\text { pmm }\end{array}$ & $\begin{array}{c}>15 \\
\mathrm{pmm}\end{array}$ & \\
\hline Northern & $\begin{array}{l}1,901 \\
(98.9)\end{array}$ & $\begin{array}{l}15 \\
(0.8)\end{array}$ & $\begin{array}{c}7 \\
(0.4)\end{array}$ & $\begin{array}{c}1,923 \\
(100.0)\end{array}$ & $\begin{array}{c}3 \\
(33.3)\end{array}$ & $\begin{array}{c}6 \\
(66.7)\end{array}$ & $0(0.0)$ & $\begin{array}{c}9 \\
(100.0)\end{array}$ \\
\hline Eastern & $\begin{array}{l}2,543 \\
(96.9)\end{array}$ & $\begin{array}{c}43 \\
(1.6)\end{array}$ & $\begin{array}{c}39 \\
(1.5)\end{array}$ & $\begin{array}{c}2,625 \\
(100.0)\end{array}$ & $\begin{array}{c}19 \\
(32.2)\end{array}$ & $\begin{array}{c}16 \\
(27.1)\end{array}$ & $\begin{array}{c}24 \\
(40.7)\end{array}$ & $\begin{array}{c}59 \\
(100.0)\end{array}$ \\
\hline Khartoum & $\begin{array}{c}928 \\
(98.5)\end{array}$ & $\begin{array}{c}6 \\
(0.6)\end{array}$ & $\begin{array}{c}8 \\
(0.8)\end{array}$ & $\begin{array}{c}942 \\
(100.0)\end{array}$ & $\begin{array}{c}1 \\
(33.3)\end{array}$ & $\begin{array}{c}2 \\
(66.7)\end{array}$ & $\begin{array}{c}0 \\
(0.0 \%)\end{array}$ & $\begin{array}{c}3 \\
(100.0)\end{array}$ \\
\hline Central & $\begin{array}{l}3,508 \\
(99.1)\end{array}$ & $\begin{array}{l}14 \\
(0.4)\end{array}$ & $\begin{array}{c}17 \\
(0.5)\end{array}$ & $\begin{array}{c}3,539 \\
(100.0)\end{array}$ & $\begin{array}{c}10 \\
(66.7)\end{array}$ & $\begin{array}{c}5 \\
(33.3)\end{array}$ & $\begin{array}{c}0 \\
(0.0)\end{array}$ & $\begin{array}{c}15 \\
(100.0)\end{array}$ \\
\hline Kordofan & $\begin{array}{l}1,668 \\
(93.8)\end{array}$ & $\begin{array}{l}47 \\
(2.6)\end{array}$ & $\begin{array}{c}64 \\
(3.6)\end{array}$ & $\begin{array}{c}1,779 \\
(100.0)\end{array}$ & $\begin{array}{c}7 \\
(17.1)\end{array}$ & $\begin{array}{c}17 \\
(41.5)\end{array}$ & $\begin{array}{c}17 \\
(41.5)\end{array}$ & $\begin{array}{c}41 \\
(100.0)\end{array}$ \\
\hline Darfur & $\begin{array}{l}1,773 \\
(87.7)\end{array}$ & $\begin{array}{c}83 \\
(4.1)\end{array}$ & $\begin{array}{l}165 \\
(8.2)\end{array}$ & $\begin{array}{c}2,021 \\
(100.0)\end{array}$ & $\begin{array}{c}26 \\
(3.2)\end{array}$ & $\begin{array}{c}112 \\
(13.6)\end{array}$ & $\begin{array}{c}685 \\
(83.2)\end{array}$ & $\begin{array}{c}823 \\
(100.0)\end{array}$ \\
\hline Upper Nile & $\begin{array}{c}395 \\
(58.6)\end{array}$ & $\begin{array}{c}232 \\
(34.4)\end{array}$ & $\begin{array}{c}47 \\
(7.0)\end{array}$ & $\begin{array}{c}674 \\
(100.0)\end{array}$ & $\begin{array}{c}14 \\
(12.6)\end{array}$ & $\begin{array}{c}73 \\
(65.8)\end{array}$ & $\begin{array}{c}24 \\
(21.6)\end{array}$ & $\begin{array}{c}111 \\
(100.0)\end{array}$ \\
\hline $\begin{array}{l}\text { Bahar-Al- } \\
\text { Gazal }\end{array}$ & $\begin{array}{c}446 \\
(34.8)\end{array}$ & $\begin{array}{c}398 \\
(31.1)\end{array}$ & $\begin{array}{c}437 \\
(34.1)\end{array}$ & $\begin{array}{c}1,281 \\
(100.0)\end{array}$ & $\begin{array}{c}44 \\
(25.3)\end{array}$ & $\begin{array}{c}63 \\
(36.2)\end{array}$ & $\begin{array}{c}67 \\
(38.5)\end{array}$ & $\begin{array}{c}174 \\
(100.0)\end{array}$ \\
\hline Equatoria & $\begin{array}{c}216 \\
(10.9)\end{array}$ & $\begin{array}{c}755 \\
(38.0)\end{array}$ & $\begin{array}{l}1,014 \\
(51.1)\end{array}$ & $\begin{array}{c}1,985 \\
(100.0)\end{array}$ & $\begin{array}{c}17 \\
(20.0)\end{array}$ & $\begin{array}{c}40 \\
(47.1)\end{array}$ & $\begin{array}{c}28 \\
(32.9)\end{array}$ & $\begin{array}{c}85 \\
(100.0)\end{array}$ \\
\hline Total & $\begin{array}{l}13,378 \\
(79.8)\end{array}$ & $\begin{array}{c}1,593 \\
(9.5)\end{array}$ & $\begin{array}{l}1,798 \\
(10.7)\end{array}$ & $\begin{array}{l}16,769 \\
(100.0)\end{array}$ & $\begin{array}{c}141 \\
(10.7)\end{array}$ & $\begin{array}{c}334 \\
(25.3)\end{array}$ & $\begin{array}{c}845 \\
(64.0)\end{array}$ & $\begin{array}{c}1,320 \\
(100.0)\end{array}$ \\
\hline
\end{tabular}

age of households having access to iodized salts as recommended in the WHO/UNICEF 2007 joint statement. It is clear that only one state has more than $90 \%$ of households with access to iodized salt in 7 states, $50-90 \%$ of households have access to iodized salt; in 5 states, $20-50 \%$ of households have access to iodized salt, and in 12 states, less than $20 \%$ of households have access to iodized salt. The percentage of households consuming adequately-iodized salt ranged from $0.2 \%$ in Northern state to $78.9 \%$ in Central Equatoria state. Only three states (Central Equatoria, Lakes, and East Equatoria) had more than $50 \%$ of households using adequatelyiodized salt.

Table 3 shows the adequacy of salt iodization according to the source of the salt by geographical area. In general, around $90 \%$ of the survey population obtained their salt from the local markets. In Darfur (28.58\%), the salt is provided by Food Aid. Nationally, only $21.2 \%$ of salts from the local markets are iodized while $89.37 \%$ of the salts from Food Aid are iodized; only $10.72 \%$ of salts from the local markets are adequately-iodized compared to $64.0 \%$ of the salts from Food Aid. The availability of iodized salt in the markets ranged from around $90 \%$ in Equatoria sector to less than $0.5 \%$ in Northern sector (Table 3).

Table 4 shows association between iodized saltuse and some assumed independent variables. The table shows that educational level of the head of the household, gender, mode of living, the region, and wealth index have strong association with the consumption of iodized salt. Households are more likely to consume iodized salt if the head of household is male, lives in urban setting or live in the areas where iodized salt is accessible in the markets. On the other hand, households are more likely to consume iodized salt if the head of household is more educated and comparatively wealthy (Table 4). 


\begin{tabular}{|c|c|c|c|}
\hline Variable & $\begin{array}{l}\text { Using iodized salt } \\
\text { No. }(\%)\end{array}$ & $\begin{array}{c}\text { Not using iodized salt } \\
\text { No. }(\%)\end{array}$ & $\begin{array}{l}\text { Chi-square value } \\
\text { and p value }\end{array}$ \\
\hline \multicolumn{4}{|c|}{ Education of the household head } \\
\hline No education & $6,627(67.9)$ & $3,127(32.1)$ & \multirow{3}{*}{$\begin{array}{c}\chi^{2}=627.658 \\
p=0.000\end{array}$} \\
\hline Primary & $3,093(80.2)$ & $765(19.8)$ & \\
\hline Secondary & $2,896(82.8)$ & $603(17.2)$ & \\
\hline \multicolumn{4}{|c|}{ Gender of the household head } \\
\hline Male & $12,282(77.7)$ & $3,531(22.3)$ & \multirow{2}{*}{$\begin{array}{c}\chi^{2}=344.985 \\
p=0.000\end{array}$} \\
\hline Female & $1,832(61.6)$ & $1,141(38.4)$ & \\
\hline \multicolumn{4}{|l|}{ Mode of living } \\
\hline Rural & $4,344(72.6)$ & $1,637(27.4)$ & \multirow{2}{*}{$\begin{array}{c}\chi^{2}=29.361 \\
p=0.000\end{array}$} \\
\hline Urban & $9,770(76.3)$ & $3,035(23.7)$ & \\
\hline \multicolumn{4}{|l|}{ Region } \\
\hline Northern Sudan & $12,935(90.0)$ & $1,445(10.0)$ & \multirow{2}{*}{$\begin{array}{c}\chi^{2}=7207.985 \\
p=0.000\end{array}$} \\
\hline Southern Sudan & $1,179(26.8)$ & $3,227(73.2)$ & \\
\hline \multicolumn{4}{|l|}{ Wealth index } \\
\hline Poorest & $1,831(52.2)$ & $1,680(47.8)$ & \multirow{5}{*}{$\begin{array}{c}\chi^{2}=2659.936 \\
p=0.000\end{array}$} \\
\hline Second & $2,633(61.8)$ & $1,626(38.2)$ & \\
\hline Middle & $3,282(77.9)$ & $933(22.1)$ & \\
\hline Fourth & $3,619(93.2)$ & $264(6.8)$ & \\
\hline Richest & $2,749(94.2)$ & $169(5.8)$ & \\
\hline
\end{tabular}

\section{DISCUSSION}

At the national level, there is an overall improvement in the percentage of households using adequately-iodized salt from less than 1\% in 2000 to $14.4 \%$ in 2006 (8) but this is still a very low coverage for USI goal. UNICEF estimates that the average in developing countries had reached $70 \%$ in 2000 (2). Among the countries neighbouring Sudan, the lowest coverage of households with adequatelyiodized salt is found in Ethiopia and Chad, which have $20 \%$ and $56 \%$ coverage respectively. Kenya, Libyan Arab Jamahiriya, and Uganda achieved the goal of Universal Salt Iodization. Congo and Egypt are in progress to achieve this goal (6).

There are wide variations in people's access to iodized salt among the states, ranging from 96.9\% in Central Equatoria to $0.4 \%$ in Gezira state. It is the first time ever since the inception of the programme in Sudan to report these high levels of access to iodized salt in some states. Similar variations were reported in other countries, like Bangladesh and India $(15,16)$. The implementation of the salt iodization programmes varies between states, thus resulting in different levels in people's access to iodized salt. Based on the UNICEF/WHO joint statement and classification (17), the programme priority interventions in the state level must be based on the situation of the USI programme in each state; this will enhance the utilization in federal system and the autonomous level of governance.

The variation in iodized salt consumption is largely due to the great variation among states regarding the availability of iodized salt in the markets. In Equatoria region, $89.1 \%$ of the salts in the local markets are iodized, and $51.1 \%$ are adequately iodized. On the other hand, $98.9 \%$ of the salts in the local markets in the Northern region are not iodized. The main improvement occured in Southern and Darfur states. Markedly significant changes observed in southern states are likely due to the improvement in the security situation as a result of the Comprehensive Peace Agreement (CPA) signed by the Government of Sudan and the Sudan People's Liberation Movement (SPLM) in 2005 (12). Salts in these states mainly come from Kenya and Uganda across the borders, and the percentage of households using adequately-iodized salt in Kenya and Uganda is $91 \%$ and $96 \%$ respectively $(6,8)$. On the other hand, the coverage in the Darfur states is high because Food Aid, in recent years, increased distribution in the region in response to the civil conflict and humanitarian crisis. Generally, salts from Food Aid are more likely to be iodized compared to only the fifth of the salt samples available in the local markets. 
The main source of salt in other parts of Sudan is in the Red Sea state, and a small quantity of iodized salt is imported from Saudi Arabia, Turkey, and countries in the Middle East (10). The iodine levels are not at the range recommended by the Sudan Ministry of Health, thus need to be monitored at entry-port to ensure adherence to the national specification. If production of iodized salt is ensured from all local producers, the majority of population will have access to iodized salt.

Although there is considerable international support to the National USI programme, especially in the form of donation of salt iodization machines and potassium iodate, iodized salt production is stagnant (18). This reflects the low awareness and weak political commitment toward USI and IDD control $(18,19)$. Many ministerial decrees were issued by ministers of health, requesting salt manufacturers to produce iodized salt (18), in addition to legislations banning the sale of non-iodized salt in three states. However, the implementation and enforcement of legislations are of concern. Instead of wasting IDD/USI programme resources to pass new legislations for banning non-iodized salt in this nonsupportive political environment, the programme can use the existing laws and legislations to enforce USI strategy. The programme should work with Sudan Standardization and Metrology Organization (SSMO) and Consumer Protection Organization to issue compulsory salt specification for the nation and develop monitoring system, based on the National Standardization and Metrology Law 2008 (20) and other laws, like National Public Health Law (2008) (21), Food Inspection Law (1973) (22), National Council for Childhood Care Law (2008) (23), and School Health Law (1974) (24) .

All examined factors, such as education of the head of the household, gender, mode of living, the regions, and wealth index, are significant at $\mathrm{p}<0.05$ in bivariate analysis. This means that all these variables are strongly associated with iodized salt-use. This reflects clearly that Universal Salt Iodization is a public-health policy issue rather than individual choice. Whenever and wherever iodized salt alone is available at the markets, people will use it even though they are not aware of its benefits.

The IDD programme has no monitoring and evaluation system; monitoring of IDD prevention and control programmes is crucial to ensure that additional iodine intake is effective in reducing the deficiency while preventing excessive intake that may lead to adverse health consequences (3). The only national IDD survey was conducted in 1997; there is an urgent need to conduct national IDD survey to update the country data, using the $\mathrm{WHO} /$ UNICEF/ICCIDD guidelines and to establish monitoring systems.

\section{Limitations}

Using only rapid salt-testing kits to determine iodine content was one of the limitations of the study. This method needs to be supported by titration method, using the standard WHO/UNICEF/ ICCIDD guidelines. The other limitation was that we could not access the Multiple Indicators Cluster Survey (MICS, 2000) datasets to re-analyze it as we did with SHHS data; this was important since it was possible to explore the trend in population coverage with iodized salt.

\section{Conclusions}

The population coverage with iodized salt in Sudan remains very low. The awareness and political support for the USI programme is very weak. National legislation banning non-iodized salt does not exist. Utilization of already-existing laws, like the National Standardization and Metrology Law (2008), to develop a compulsory national salt specification will accelerate the USI in Sudan. Establishment of monitoring systems, including monitoring the market availability of iodized salt, is crucial. National IDD survey is urgently needed to update the country data and for future planning.

\section{ACKNOWLEDGEMENTS}

We thank the Sudan Household Health Survey, 2006 coordinating authority who gave us the survey data and all dedicated data-collection workers who participated in this national survey.

\section{REFERENCES}

1. Hetzel BS. An overview of the global program for the elimination of brain damage due to iodine deficiency. In: Hetzel BS, editor. Towards the global elimination of brain damage due to iodine deficiency: a global program for human development with a model applicable to a variety of health, social and environmental problems. New Delhi: Oxford University Press, 2004:23-37.

2. United Nations Children's Fund. Sustainable elimination of iodine deficiency: progress since the 1990 World Summit for Children. New York, NY: United Nations Children's Fund, 2008. 43 p.

3. World Health Organization. Assessment of iodine deficiency disorders and monitoring their elimination: 
a guide for programme managers. 3rd ed. Geneva: World Health Organization, 2007. 97 p.

4. Mannar MGV. Iodized salt for the elimination of IDD. In: Hetzel BS, editor. Towards the global elimination of brain damage due to iodine deficiency: a global program for human development with a model applicable to a variety of health, social and environmental problems. New Delhi: Oxford University Press, 2004:195-211.

5. Delange F, Hetzel BS. The scientific basis for the elimination of brain damage due to iodine deficiency. In: Hetzel BS, editor. Towards the global elimination of brain damage due to iodine deficiency: a global program for human development with a model applicable to a variety of health, social and environmental problems. New Delhi: Oxford University Press, 2004:151-94.

6. Network for Sustained Elimination of Iodine Deficiency. Global scorecard 2010. Ottawa: Network for Sustained Elimination of Iodine Deficiency, 2010. 4 p. (http://www.iodinenetwork.net/documents/scorecard-2010.pdf, accessed on 9 March 2010).

7. Sudan. Federal Ministry of Health. Universal Salt Iodization Program in the Republic of Sudan: a status consultant report. Khartoum: Nutrition Department, Republic of Sudan, 2005:5-31.

8. Sudan. Federal Ministry of Health. Multiple indicator cluster survey, 2000: Sudan-final report. Khartoum: Federal Ministry of Health, Republic of Sudan, 2001. $80 \mathrm{p}$.

9. Medani AM, Elnour AA, Saeed AM. Endemic goitre in the Sudan despite long-standing programmes for the control of iodine deficiency disorders. Bull World Health Organ 2011;89:121-6.

10. Izzeldin HS, Crawford MA, Jooste PL. Population living in the Red Sea State of Sudan may need urgent intervention to correct the excess dietary iodine intake. Nutr Health 2007;18:333-41.

11. United Nations Children's Fund. UNICEF Sudan technical briefing paper 2: Universal Salt Iodization. Khartoum: United Nations Children's Fund, 2007. 4 p.

12. Gaffar AM, Mahfouz MS. Peace impact on health: population access to iodized salt in south Sudan in post-conflict period. Croat Med J 2011;52:178-82.

13. Central Bureau of Statistics. 5th Sudan population and housing census 2008: priority results. Khartoum: Central Bureau of Statistics, 2009. 27 p. (http://southsudaninfo.net/wp-content/uploads/reference_library/reports/5th_sudan_census26_april_2009.pdf, accessed on 17 October 2012).

14. Sudan. Federal Ministry of Health. Sudan Household Health Survey. Khartoum: Federal Ministry of Health, Republic of Sudan, 2007:74-76.

15. Gulshan A. Many Bangladeshi adolescent girls and pregnant women are iodine deficient. IDD Newsl 2010;36:9-12.

16. Agarwal S, Sethi V, Sharma D, Vaid M, Agnihotri A, Sindhwani A et al. Consumption of iodized salt among slum households of North-East Delhi, India. Indian J Community Med 2009;34:368-9.

17. International Council for Control of Iodine Deficiency Disorders. Reaching optimal iodine nutrition in pregnant and lactating women and young children. IDD Newsl 2008;27:1-3.

18. Bani I. Accelerating progress on salt iodisation in Sudan: time for action. Disasters 2007;31(Suppl 1):S13949.

19. Izzeldin SH, Crawford MA, Ghebremeskel K. Salt fortification with iodine: Sudan situation analysis. Nutr Health 2009;20:21-30.

20. Sudan. Ministry of Justice. National Standardization and Metrology Law 2008. Khartoum: Ministry of Justice, Republic of Sudan, 2010:1-32.

21. Sudan. Ministry of Justice. National Public Health Law 2008. Khartoum: Ministry of Justice, Republic of Sudan, 2010:1-35.

22. Sudan. Ministry of Justice. Food Inspection Law 1973. Khartoum: Ministry of Justice, Republic of Sudan, 2010:1-15.

23. Sudan. Ministry of Justice. National Council for Childhood Care Law 2008. Khartoum: Ministry of Justice, Republic of Sudan, 2010.1-17.

24. Sudan. Ministry of Justice. School Health Law 1974. Khartoum: Ministry of Justice, Republic of Sudan, 2010:1-16. 